\title{
ANALISIS PEMASARAN IKAN BANDENG DI DESA PITUE KECAMATAN MA'RANG KABUPATEN PANGKEP
}

\author{
Nurdiana $^{1}$, Marhawati $^{2}$ \\ ${ }^{1}$ Pendidikan ekonomi Universitas Negeri Makassar \\ Email : nurdiananurdin.unm@gmail.com \\ ${ }^{2}$ Pendidikan ekonomi Universitas Negeri Makassar \\ Email : marhawatiunm@unm.ac.id
}

\begin{abstract}
The purpose of this study to determine the pattern of marketing channels, marketing margin and the level of marketing efficiency Pitue fish in the Village, District Ma'rang Pangkep. This research uses descriptive method. The analysis used data analysis techniques and marketing agency channel, analysis of market behavior, marketing margin analysis, analysis of the share of farmers and marketing efficiency analysis. The results showed fish marketing channels is the marketing channel (milkfish aquaculture farmers, traders, retailers, end consumers) and II (pond fish farmers, retailers, consumers end), which is the most efficient channel marketing II. Marketing margins in the channel I is greater than the margin of marketing channels II. Marketing of fish in the pitue village district ma'rang Pangkajene archipelago efficient, because the value of marketing efficiency of marketing channels I and II was 11.52 per cent and 7.10 per cent less than 50 per cent.
\end{abstract}

Keyword: Efficiency, Marketing, Milkfish

\begin{abstract}
Abstrak. Tujuan penelitian ini untuk mengetahui pola saluran pemasaran, margin pemasaran dan tingkat efisiensi pemasaran ikan bandeng di Desa Pitue, Kecamatan Ma'rang Kabupaten Pangkep. Penelitian ini menggunakan pendekatan metode deskriptif. Tehnik analisis data digunakan Analisis lembaga dan saluran pemasaran, analisis perilaku pasar, analisis margin pemasaran, analisis farmer's share dan analisis efisiensi pemasaran. Hasil penelitian menunjukkan saluran pemasaran ikan bandeng merupakan saluran pemasaran (petani tambak ikan bandeng, pedagang pengumpul, pedagang pengecer, konsumen akhir)dan II (petani tambak ikan bandeng, pedagang pengecer, konsumen akhir), dimana saluran pemasaran II yang paling efisien. Margin pemasaran pada saluran I lebih besar dibandingkan dengan margin pemasaran saluran II. Pemasaran ikan bandeng Di Desa Pitue Kecamatan Ma'rang Kabupaten Pangkajene dan Kepulauan sudah efisien, karena nilai efisiensi pemasaran dari saluran pemasaran I dan II adalah 11,52 persen dan 7,10 persen lebih kecil dari 50 persen.
\end{abstract}

Kata kunci : Efisiensi, Pemasaran, Ikan Bandeng

\section{PENDAHULUAN}

Pembangunan sektor perikanan adalah suatu proses perubahan dan pembaharuan yang berencana menuju tatanan masyarakat, khususnya masyarakat perikanan yang lebih baik. Perikanan mempunyai peranan yang cukup penting, terutama dikaitkan dengan upaya meningkatkan kualitas dan kuantitas produk perikanan, menghasilkan protein hewani dalam rangka memenuhi kebutuhan pangan dan gizi, meningkatkan ekspor, menyediakan bahan baku industri, memperluas lapangan kerja dan kesempatan berusaha, serta mendukung pembangunan wilayah dan tetap memperhatikan kelestarian dan fungsi lingkungan hidup.

Salah satu komoditi perikanan yang memiliki prospek cukup baik untuk dikembangkan adalah Ikan Bandeng (Chanos chanos). Budidaya Ikan Bandeng banyak dilakukan antara lain karena mampu beradaptasi dengan suhu lingkungan yang ditempatinya dengan kisaran $15^{\circ}-40^{\circ}$ Celcius. 
Kabupaten Pangkep merupakan salah satu sentra produksi ikan bandeng di Sulawesi Selatan dengan total produksi 11. 823 ton pada tahun 2014 (Dinas Kelautan dan Perikanan Kab. Pangkep, 2015) yang tersebar di enam
Kecamatan meliputi Kecamatan, Pangkajene, Bungoro, Labbakang, Ma'rang, Segeri, dan Mandalle. Adapun produksi ikan bandeng tiap kecamatan dapat dilihat pada tabel berikut ini.

Tabel. 1. Produksi Ikan Bandeng Tiap Kecamatan di Kabupaten Pangkep Tahun 2015.

\begin{tabular}{lccccc}
\multirow{2}{*}{$\begin{array}{c}\text { Nama } \\
\text { Kecamatan }\end{array}$} & \multicolumn{5}{c}{ Jumlah Produksi (Ton) } \\
\cline { 2 - 6 } & $\mathbf{2 0 1 0}$ & $\mathbf{2 0 1 1}$ & $\mathbf{2 0 1 2}$ & $\mathbf{2 0 1 3}$ & $\mathbf{2 0 1 4}$ \\
\hline Pangkajene & $2.380,0$ & $2.226,8$ & $2.369,2$ & $2.406,3$ & $2.447,0$ \\
Bungoro & $1.145,7$ & $1.056,7$ & $1.035,0$ & 1068,4 & $1.065,5$ \\
Labbakang & $2.683,9$ & $2.441,8$ & $2.396,2$ & $2.918,4$ & $3.167,8$ \\
Ma'rang & $2.560,5$ & $2.348,5$ & $2.537,9$ & $2.530,9$ & $2.551,8$ \\
Segeri & $1.038,3$ & $1.227,9$ & $1.273,7$ & $1.321,2$ & $3.935,0$ \\
Mandalle & 497,9 & 487,4 & 470,5 & 513,6 & 519,0 \\
\hline
\end{tabular}

Sumber : Dinas Kelautan dan Perikanan Kabupaten. Pangkep , 2015

Dari tabel 1 dapat dilihat bahwa Kecamatan Ma'rang merupakan salah satu Kecamatan dengan total jumlah produksi ikan bandeng terbesar ketiga di Kabupaten Pangkep dengan sumbangsih produksi pada tahun 2014

Tabel 2. Data luas lahan tambak dan produksi ikan bandeng tiap desa di Kecamatan Ma'rang Kabupaten Pangkep

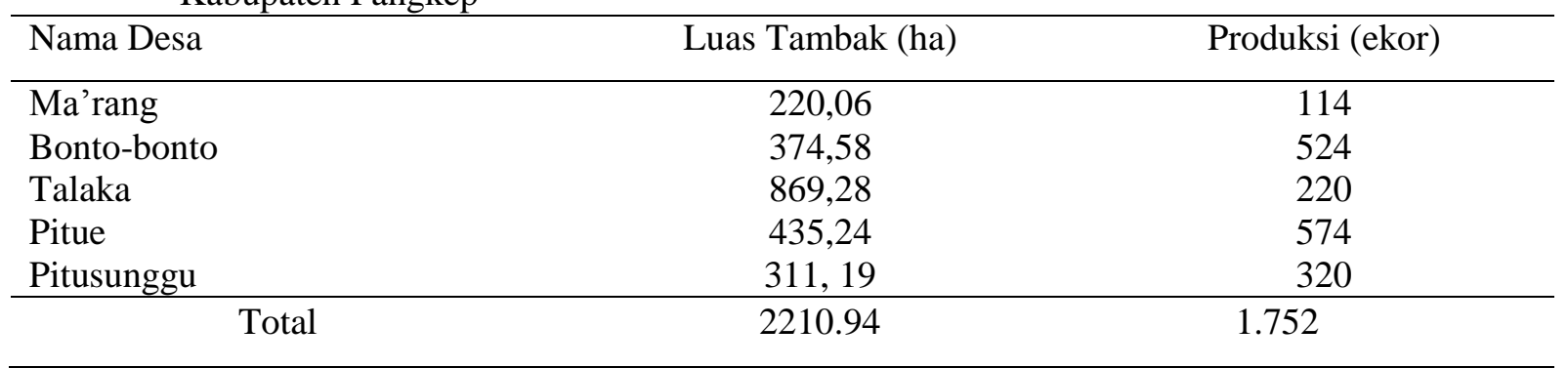

Sumber : Dinas Kelautan dan Perikanan Kabupaten. Pangkep, 2015
Pada tabel 2 dapat dilihat bahwa Desa Pitue Kecamatan Ma'rang Kabupaten Pangkep merupakan salah satu sentra produksi Ikan Bandeng. Sebagian besar mata pencaharian masyarakatnya adalah membudidayakan Ikan Bandeng. Budidaya Ikan Bandeng di Desa Pitue Kecamatan Ma'rang sudah berlangsung cukup lama.

Pemasaran merupakan hal yang paling penting dalam menjalankan sebuah usaha perikanan karena pemasaran merupakan tindakan ekonomi yang berpengaruh terhadap tinggi rendahnya pendapatan petani tambak. Produksi yang tinggi akan sia-sia jika harga jualnya rendah. Oleh karena itu tingginya produksi tidak selalu memberikan keuntungan sebesar 2.551, 8 ton yang di produksi dari 5 desa yakni Ma'rang, Bonto-bonto, Talaka, Pitue, Pitusunggu. Adapun luas tambak dan produksi ikan bandeng dapat dilihat pada tabel berikut. yang tinggi tanpa disertai pemasaran yang baik dan efisien.

Untuk mendapatkan keuntungan yang optimal, maka diperlukan adanya sistem pemasaran yang efisisen yang mampu mengadakan pembagian keuntungan yang adil kepada semua pihak baik produsen maupun lembaga pemasaran. Panjang pendeknya saluran pemasaran dapat menyebabkan adanya selisih harga di tingkat konsumen dengan harga yang diterima petani. Harga yang tingi di tingkat konsumen belum tentu memberikan keuntungan yang tinggi bagi produsen ikan bandeng.

Marjin pemasaran yang diperoleh dari perbedaan harga jual pembudidaya dan harga yang dibayarkan konsumen akhir dapat 
menggambarkan seberapa efisienkah saluran pemasaran yang ditempuh oleh pembudidaya. Semakin besar selisih harga jual pembudidaya dengan harga yang dibayarkan konsumen akhir menjadi indikasi akan semakin tidak efisien saluran pemasaran, dan semakin sedikit farmer's share yang diterima oleh pembudidaya.

Berdasarkan uraian tersebut, maka bagaimana pola saluran pemasaran, besar margin pemasaran ikan bandeng pada masing-masing saluran pemasaran, dan bagaimana tingkat efisiensi pemasaran ikan bandeng berdasarkan margin pemasaran, bagian harga yang diterima produsen (farmer share) di Desa Pitue Kecamatan Ma'rang Kabupaten Pangkep, menarik untuk dikaji.

\section{METODE PENELITIAN}

Penelitian ini menggunakan penedekatan metode deskriptif yaitu metode yang memusatkan diri pada pemecahan masalah yang ada pada masa sekarang pada masalahmasalah yang aktual kemudian data yang dikumpulkan mula-mula disusun, dijelaskan kemudian dianalisis (Surakhmad, 1994). Sedangkan teknik penelitian yang digunakan adalah metode survey, yaitu penelitian yang mengambil sampel dari suatu populasi yang menggunakan kuesioner sebagai alat untuk mengumpulkan data (Singarimbun dan Efendi, 1995)

Penelitian ini dilakukan di desa Pitue Kecamatan Ma'rang Kabupaten Pangkep. Penentuan lokasi penelitian dilakukan secara sengaja (purposive), dengan pertimbangan bahwa desa Pitue adalah salah satu sentra produksi ikan bandeng.

Data yang dipergunakan dalam penelitian ini terdiri dari data kualitatif dan kuantitatif. Adapun sumber data yang digunakan adalah data primer dan data sekuder. Data primer diperoleh dari sumber langsung dari petani tambak ikan bandeng serta lembaga yang terlibat dalam rantai pasokikan bandeng. Sedangkan data sekunder diperoleh dari dokumen, laporan tertulis, serta instansi yang ada kaitannya dengan penelitian ini.

Populasi penelitian ini adalah petani tambak ikan bandeng, pedagang perantara pada berbagai tingkatan sampai konsumen yang berdomisisli di kabupaten Pangkep. Populasi petani tambak yang ada di desa Pitue sebanyak
189 Orang Untuk petani tambak jumlah sampel yang diambil dalam penelitian ini adalah 15 persen atau sekitar 30 orang dari 189 populasi petani tambak. Sedangkan cara penarikan sampel dilakukan secara acak sederhana (random sampling) karena populasinya homogen. Sedangkan lembaga pemasaran belum ditetapkan jumlahnya, utamanya lembaga yang terlibat dalam pemasaranikan bandeng, penentuan ini akan dilakukan dengan metode bola salju (snowball sampling) atau sampling rujukan berantai.

Untuk mengetahui pola saluran pemasaran dan perantara lembaga pemasaran di desa Pitue pada tingkat lembaga pemasaran digunakan analisa deskriptif. Sedangkan untuk mengetahui biaya dan marjin pemasaran di tingkat lembaga pemasaran dalam saluran pemasaran digunakan alat analisis biaya marjin, marjin pemasaran, yaitu dengan menghitung besarnya biaya, keuntungan dan marjin pemasaran pada tiap lembaga pemasaran pada berbagai saluran.

1. Analisis Lembaga dan Saluran Pemasaran

Analisis ini dilakukan untuk mengidentifikasikan saluran pemasaran yang ada untuk mengetahui proses penyampaian produk dari tangan produsen ke konsumen. Selain itu, melalui analisis saluran dan lembaga pemasaran dapat dilihat fungsi-fungsi pemasaran yang dilakukan oleh setiap lembaga pemasaran yang terlibat. Dengan analisis lembaga pemasaran ini dapat dilihat sejauh mana peran lembaga pemasaran dalam menjaga mutu produk.

2. Analisis Perilaku Pasar

Dahlan Hamid (1977:94) "Perilaku pasar Ikan Bandeng dapat dianalisis dengan mengamati praktek penjualan dan pembelian, sistempenentuan dan pembayaran harga, dan kerjasama diantara lembaga-lembaga pemasaran. "Perilaku pasar akan sangat jelas pada saat beroperasi, misalkan dalam penentuan harga, pangsa pasar, penjualan, siasat pemasaran dan lain sebagainya.

3. Analisis Marjin Pemasaran

Analisis marjin pemasaran digunakan untuk melihat tingkat efisiensi produk Ikan Bandeng. Marjin pemasaran adalah merupakan perbedaan harga yang dibayar kepada produsen dan harga yang dibayar konsumen. Perhitungan analisis marjin pemasaran dilakukan untuk 
mengetahui perbedaan harga per satuan di tingkat produsen atau tingkat konsumen yang terjadi pada rantai pemasaran. Secara matematis dapat dirumuskan sebagai berikut:

a. Margin Pemasaran

$$
\begin{aligned}
& \mathrm{MP}=\mathrm{HBK}-\mathrm{HJP} \\
& \mathrm{MP}=\frac{H J P}{H J K} X 100 \% \ldots \ldots \text { Azzaino }(1982: 22)
\end{aligned}
$$

\section{Dimana :}

MP $=$ Margin Pemasaran Ikan Bandeng $(\mathrm{Rp} / \mathrm{Kg})$

HBK = Harga Beli Konsumen Ikan Bandeng $(\mathrm{Rp} / \mathrm{Kg})$

HJP = Harga Jual Produsen Ikan Bandeng $(\mathrm{Rp} / \mathrm{Kg})$

Margin Pemasaran Total dihitung dengan menggunakan rumus :

MPT $=p f-p r$

Dimana :

$$
\begin{aligned}
& M P T=\text { Margin Pemasaran Total } \\
& \text { Pf } \quad=\text { Harga Di Tingkat Penjual Pertama } \\
& (\mathrm{Rp} / \mathrm{Kg}) \\
& \text { Pr } \quad=\text { Harga Di Tingkat Pembeli Akhir } \\
& (\mathrm{Rp} / \mathrm{Kg})
\end{aligned}
$$

\section{Analisis Farmer'sShare}

Limbong dan Sitorus (1987:58) menyatakan analisis ini digunakan untuk membandingkan harga yang diterima produsen atau petani dengan harga yang dibayarkan oleh konsumen akhir yang biasa disebut dengan farmer's share." Farmer's share berhubungan negatif dengan marjin pemasaran, semakin tinggi marjin pemasaran maka bagian yang akan diperoleh produsen atau petani semakin rendah.

Bagian yang diterima petani tambak ikan bandeng disebut farmer's share (persen) dapat dihitung dengan menggunakan rumus :

Farmer's Share $=\frac{P f}{P r} X 100 \%$
Dimana :

$$
\text { Pf }=\underset{(\mathrm{Rp} / \mathrm{Kg})}{\text { Harga Di Tingkat Penjual Pertama }}
$$

$\operatorname{Pr}=$ Harga Di Tingkat Pembeli Akhir $(\mathrm{Rp} / \mathrm{Kg})$

\section{Efisiensi Pemasaran}

Efisiensi pemasaran adalah maksimisasi dari ratio input dan output. Input berupa biayabiaya yang dikeluarkan oleh lembaga pemasaran yang terlibat dalam memasarkan hasil perikanan. Sedangkan output adalah kepuasan dari konsumen. Perubahan yang mengurangi biaya input tanpa mengurangi kepuasan konsumen akan meningkatkan efisiensi sedangkan perubahan yang mengurangi biaya input tetapi mengurangi kepuasan konsumen akan menurunkan efisiensi pemasaran.

$$
E p=\frac{\text { Biaya Pemasaran }}{\text { Nilai Produk Yang Dipasarkan }} X 100 \%
$$

Jika : Ep $\leq 50 \%$ maka saluran pemasaran dikatakan efisien dan Ep $>50 \%$ maka saluran pemasaran dikatakan tidak efisien

\section{HASIL DAN PEMBAHASAN}

Sebagian besar petani tambak menjual ikan bandeng melalui pedagang pengumpul karena mengenal dekat pedagang pengecer. Bagi sebagian petani tambak menjual ikan bandeng kepada pedagang pengumpul sangat mudah dilakukan karena tidak perlu mencari pedagang pengecer terlebih dahulu untuk menawarkan ikan bandeng. Namun, bagi sebagian lainnya menjual langsung ke pedagang pengecer adalah paling efesien dilakukan karena keuntungan yang diperoleh lebih tinggi.

Saluran pemasaran ikan bandeng yang terbentuk melibatkan 3 lembaga pemasaran. Lembaga pemasaran tersebut terdiri dari petani tanbak ikan bandeng, pedagang pengumpul, dan pedagang pengecer. Adapun rantai pemasaran ikan bandeng sebagai berikut:

\section{1) Saluran I : Petani ikan bandeng $\longrightarrow$ pedagang pengumpul $\longrightarrow$ pedagang pengecer $\longrightarrow$ konsumen akhir \\ 2) Saluarn II $:$ Petani ikan bandneg $\longrightarrow$ pedagang pengecer $\longrightarrow$ konsumen akhir.}

Saluran pemasaran yang terbentuk merupakan saluran pemasaran satu tingkat (one- levelchanel ) yaitu saluran 2 dan saluran pemsaran dua tingkat ( two-level- chanel) yaitu pada saluran I. 
Saluran pemasaran ikan bandeng yang terbentuk di Desa Pitue Kecamatan Ma'rang
Kabupaten Pangkep dapat dilihat pada gambar 1

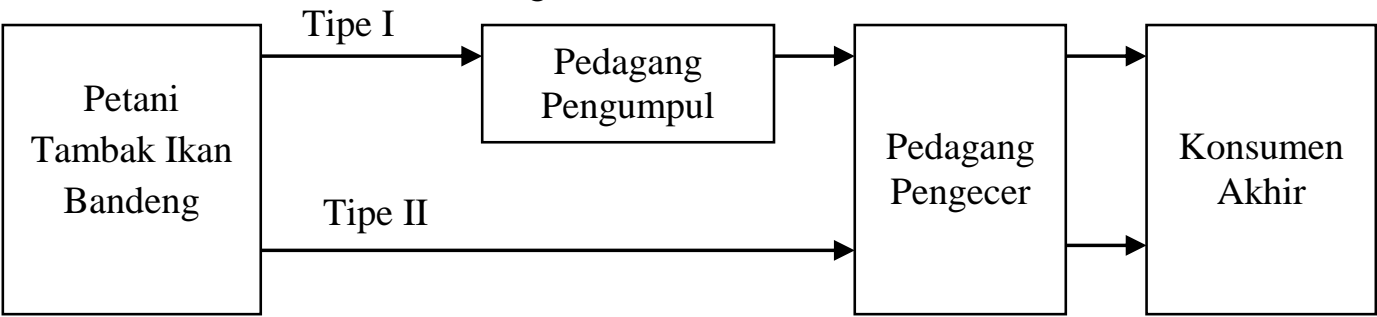

Gambar 1. Saluran Pemasaran Ikan Bandeng Di Desa Pitue Kecamatan Ma'rang Kabupaten Pangkajene dan Kepulauan.

Pada gambar 1 menunjukkan petani menggunakan 2 saluran pemasaran untuk menjual ikan bandeng ukuran konsumsi yaitu kepada pedagang pengumpul atau pedagang pengecer. Pedagang pengecer hanya mampu membeli ikan bandeng dalam jumlah kecil untuk mengurangi resiko tidak laku terjualnya ikan bandeng di pasar.

Pemasaran ikan bandeng yang cepat dan menguntungkan petani tambak, memerlukan saluran pemasaran yang tepat. Saluran pemasaran ikan bandeng yang terbentuk di Desa Pitue kecamatan Ma'rang kabupaten Pangkep menggunakan saluran I karena petani tambak biasa menjual seluruh hasil produksinya ke pedagang pengumpul. Sedangkan saluran 2 jarang dilakukan petani tambak karena selain pedagang pengecer membeli ikan bandeng dalam jumlah kecil.

Analisis margin pemasaran ikan bandeng ini dilakukan dengan menghitung biaya-biaya yang dilakukan oleh tiap-tiap lembaga saluran pemasaran yang berperan dalam memasarkan ikan bandeng mulai dari pedagang pengumpul sampai kepada konsumen akhir. Biaya pemasaran masing-masing lembaga saluran pemasaran ikan bandeng di Desa Pitue Kecamatan Ma'rang kabupaten Pangkep dapat dilihat sebagai berikut :

\section{Margin Pemasaran Saluran I :}

Margin Pemasaran

$$
\begin{aligned}
& \text { a) Pedagang Pengumpul } \\
& \begin{aligned}
\text { MP } & =\text { HBK-HJP } \\
& =\text { Rp } 20.500-\text { Rp } 17.500 \\
& =\text { Rp. } 3000 / \mathrm{kg}
\end{aligned}
\end{aligned}
$$

b) Pedagang Pengecer

$$
\begin{aligned}
\text { MP } & =\text { HBK-HJP } \\
& =\text { Rp } 24.000-\text { Rp } 20.500 \\
& =\text { Rp. } 3500 / \mathrm{kg}
\end{aligned}
$$

Margin Pemasaran Total

$$
\begin{aligned}
& M P T=P f-P r \\
& M P T=24.000-17.500
\end{aligned}
$$$$
=\text { Rp. } 6500 / \mathrm{kg}
$$

2. Margin Pemasaran Saluran II

Margin Pemasaran Pedagang pengecer

$$
\begin{aligned}
\text { MP } & =\text { HBK-HJP } \\
& =\text { Rp } 24.000-\mathrm{Rp} 19.000 \\
& =\text { Rp. } 5000 / \mathrm{kg}
\end{aligned}
$$

Dari kedua saluran pemasaran ikan bandeng di daerah penelitian, margin pemasaran terbesar adalah pada saluran 2 yaitu sebesar $\mathrm{Rp}$ $5.000 / \mathrm{kg}$. Hal ini disebabkan karena pedagang pengecer membeli langsung ikan bandeng kepada petani tambak seharga Rp 19.000/kg, kemudian pedagang pengecer tersebut menjual kepada konsumen akhir di pasar seharga Rp. $24.000 / \mathrm{kg}$

\section{a. Saluran Pemasaran I}

Untuk melihat biaya pemasaran pada saluran I ikan bandeng di Desa Pitue dapat dilihat pada tabel 3 . 
Tabel 3. Biaya Pemasaran Pada Saluran Pemasaran I Ikan Bandeng Di Desa Pitue Kecamatan Ma'rang Kabupaten Pangkep.

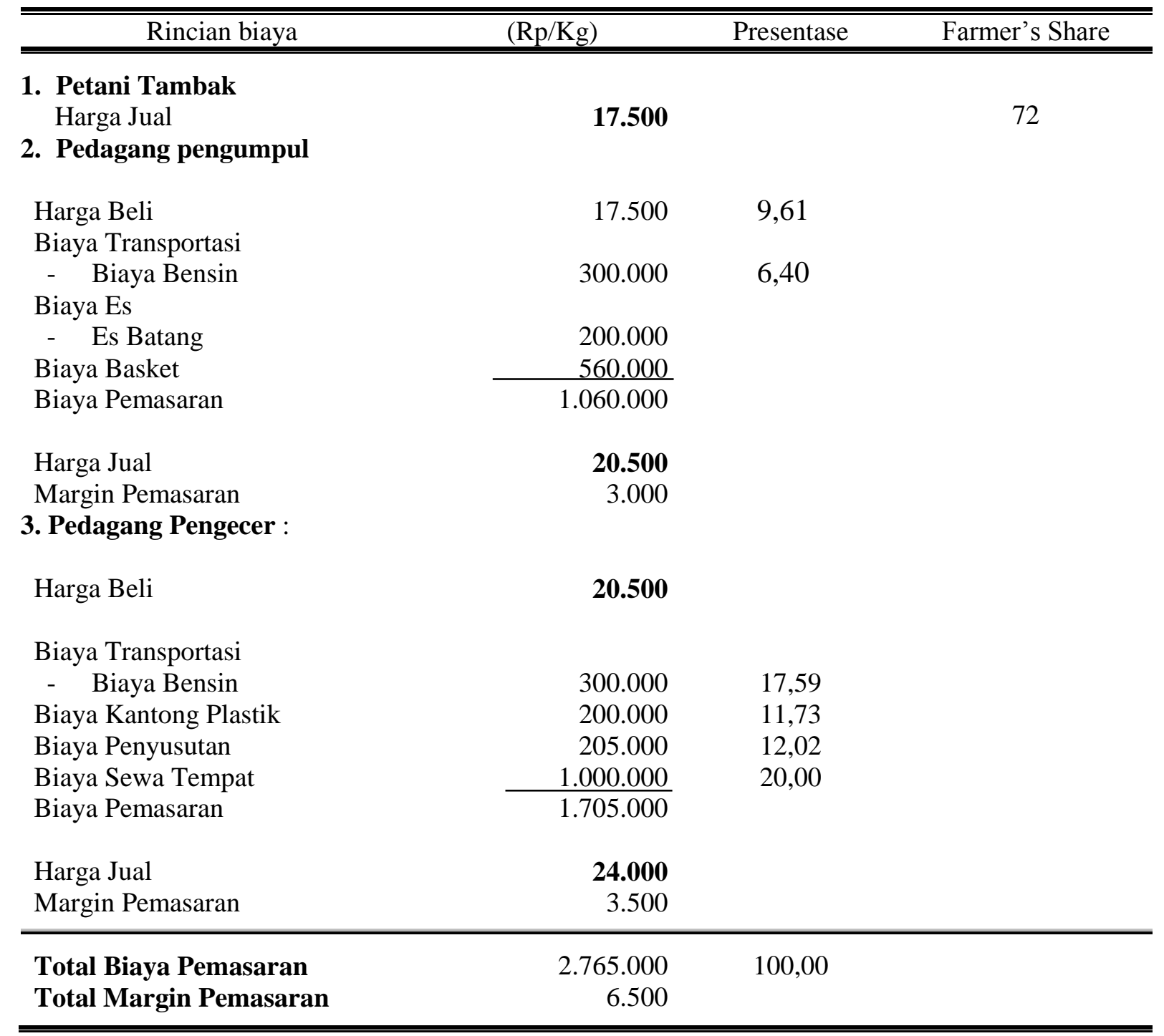

Sumber : Data Primer (diolah) 2016

Tabel 3 Menunjukkan bahwa pedagang pengumpul di daerah penelitian mengeluarkan biaya transportasi sebesar Rp. 300/kg. Di samping itu pedagang pengumpul mengeluarkan biaya berupa pembelian es batang dan pengadaan tempat penampungan ikan berupa basket dengan biaya $\mathrm{Rp} 70.000 /$ basket, dengan kapasitas muatan 125 ekor ikan per basket .Hal ini dikarenakan pedagang pengumpul menampung ikan bandeng terlebih dahulu sebelum di jual ke pedagang pengecer. Biasanya pedagang pengumpul menampung ikan bandeng ikan bandeng sampai ada pedagang yang membeli.Pedagang pengecer mengeluarkan biaya trasportasi sebesar Rp 300/kg. Biaya kantong plastik Rp 200/kg, biaya sewa tempat sebesar Rp 1.000/kg. Adapun biaya penyusutan apabila terdapat ikan yang rusak dengan biaya Rp. 205/Kg.

b. Saluran Pemasaran II

Untuk melihat biaya pemasaran pada saluran 2 ikan bandeng di Desa Pitue dapat dilihat pada tabel 4 . 
Tabel 4. Biaya Pemasaran Pada Saluran II Ikan Bandeng Di Desa Pitue. 2016

\begin{tabular}{lrrr}
\hline \multicolumn{1}{c}{ Rincian biaya } & $(\mathrm{Rp} / \mathrm{Kg})$ & Presentase & Farmer's Share \\
\hline Petani Tambak & & & 79 \\
Harga Jual & $\mathbf{1 9 . 0 0 0}$ & & \\
Pedagang Pengecer : & $\mathbf{1 9 . 0 0 0}$ & & \\
Harga Beli & & & \\
Biaya Transportasi & 300.000 & 17,59 & \\
$\quad$ Biaya Bensin & 200.000 & 1,73 & \\
Biaya Kantong Plastik & 205.000 & & \\
Biaya Penyusutan & 1.000 .000 & & \\
Biaya Sewa Tempat & 1.705 .000 & & \\
Biaya Pemasaran & $\mathbf{2 4 . 0 0 0}$ & & \\
Harga Jual & 3.500 & & \\
Margin Pemasaran & 1.705 .000 & & \\
\hline Total Biaya Pemasaran & 5.000 & & \\
Total Margin Pemasaran & & & \\
&
\end{tabular}

Sumber : Data Primer (diolah) 2016

Tabel 4 menunjukkan bahwa pada selama saluran pemasaran 2 hanya terdiri dari petani tambak dan pedagang pengecer. Biaya pemasaran yang dikeluarkan pedagang pengecer adalah Rp.1.705/kg, yang terdiri dari biaya trasnportasi Rp. 300/kg, biaya kantong plastik Rp 200/kg dan biaya sewa tempat $\mathrm{Rp} 1.000 / \mathrm{kg}$

Panjangnya saluran pemasaran I yang terbentuk akibat banyaknya lembaga pemasaran yang terlibat yaitu petani tambak, pedagang pengumpul dan pedagang pengecer. Sedangkan pada saluran pemasaran II hanya dua lembaga pemasaran yang terlibat yaitu petani tambak dan pengecer saja.

Margin pemasaran ikan bandeng di Desa Pitue juga disebabkan oleh tingginya biaya pemasaran yang dikeluarkan oleh lembaga pemasaran yang terlibat. Biaya pemasaran yang dikeluarkan oleh lembaga pemasaran pada saluran I sebesar Rp 2.765/kg lebih besar dibandingkan biaya pemasaran pada saluran II yaitu sebesar Rp 1.705/kg. Adpun biaya penyusutan apabila terdapat ikan yang rusak dengan biaya Rp. 205/Kg.

Dari uraian diatas, biaya pemasaran dan panjangnya saluran pemasaran ikan bandeng yang terjadi di Desa Pitue akan mengakibatkan semakin tingginya pola margin pemasaran yang diperoleh.

Efisiensi pemasaran merupakan salah satu ukuran (indikator) baiknya suatu pemasaran. Kegiatan ekonomi prouktif selalu berkaitan dengan efisiensi ekonomi. Di dalam rangka perbaikan tata niaga tujuan yang ingin dicapai adalah keuntungan yang maksimum dan tingkat efisiensi yang tinggi. Sistem pemasaran yang tidak efisien akan mengakibatkan kecilnya bagian dari harga yang diterima oleh produsen. Jadi, bagian harga yang dibayar oleh konsumen yang diterima oleh produsen dapat dijadikan ukuran efisiensi tata niaga.

Adapun nilai efisiensi pemasaran dari saluran pemasaran I dan saluran pemasaran II di daerah penelitian dapat dilihat sebagai berikut :

1) Saluran Pemasaran $I=11,52$ persen

2) Saluran Pemasaran $\mathrm{II}=7,10$ persen

Dari hasil analisis diperoleh nilai efisiensi pemasaran dari salauran pemasaran I dan II adalah 11,52 persen dan 7,10 persen, maka dapat dikatakan saluran pemasaran ikan bandeng di daerah penelitian adalah efisien, karena nilai efisiensi pemasaran lebih kecil dari 50 persen. Untuk lebih jelasnya perhitungan efisiensi pemasaran dapat dilihat di bawah ini : 


\section{Saluran Pemasaran I}

$$
\begin{gathered}
E p=\frac{\text { Biaya Pemasaran }}{\text { Nilai Produk yang Dipasarkan }} \times 100 \% \\
E p=\frac{2.765}{24.000} \times 100 \% \\
E p=11,52 \%
\end{gathered}
$$

2. Saluran Pemasaran II

$$
\begin{gathered}
E p=\frac{\text { Biaya Pemasaran }}{\text { Nilai Produk yang Dipasarkan }} \times 100 \% \\
E p=\frac{1.705}{24.000} \times 100 \% \\
E p=7,10 \%
\end{gathered}
$$

Untuk menentukan efisiensi pemasaran bukan hanya dilihat dari besarnya angka efisiensi pemasaran, namun ada factor lain seperti mata rantai saluran pemasaran, maka saluran pemasaran tersebut akan semakin efisien. Hal lain yang dapat menentukan adalah biaya pemasaran. Biaya pemasaran yang tinggi disebabkan panjangnya saluran pemasaran dan banyaknya fungsi pemasaran yang dilakukan oleh lembaga pemasaran. Biaya pemasaran pada saluran pemasaran I lebih tinggi dibandingkan biaya pemasaran pada saluran pemasaran II. Nilai biaya pemasaran pada saluran I adalah $\mathrm{Rp} 2.765$ dengan efisiensi pemasaran 11,52 persen, sedangkan biaya pemasaran saluran II adalah 1.705 dengan efisiensi pemasaran 7,10 persen.

Jumlah volume penjualan juga mempengaruhi efisien atau tidaknya sistem pemasaran tersebut, dimana volume yang banyak, harga murah dan jaraknya tidak jauh maka dapat dikatakan efisien. Sebaliknya volume yang dijual sedikit, harga yang tinggi dan jarak yang ditempuh cukup jauh, maka hal ini cenderung akan membuat sistem pemasaran tidak efisien

Dari kedua saluran pemasaran yang ada, saluran pemasaran II adalah yang paling efisien bagi petani tambak karena nilai efisiensi pemasaran yang lebih kecil dari pada saluran I yang disebabkan karena sedikitnya lembaga pemasaran yang terlibat.

Namun terdapat konradiksi di mna petani tambak pada umunya lebih memilih saluran I dalam memasarkan hasil produksinya. Petani tambak beranggapan menjual ke pedagang pengumpul adalah pemasaran yang paling efisien dikarenakan mudahnya transaksi yang dilakukan, yaitu dengan menghubungi pedagang pengumpul tanpa harus memikirkan transportasi apabila langsung menjual ke pedagang pengecer, dan juga pedagang pengumpul membeli ikan bandeng dalam jumlah yang lebih besar dari pada menjual kepada pedagang pengecer.

Hasil penelitian dan pembahasan yang menunjukkan bahwa pada saluran pemasaran I memiliki nilai efisiensi pemasaran sebesar 11,52 persen dan farmer's share sebesar 72 persen, sementara itu pada saluran pemasaran II memiliki nilai efisiensi pemasaran sebesar 7,10 persen dan farmer's share sebesar 79 persen, dengan demikian hal ini telah membuktikan bahwa semakin tinggi margin pemasaran, maka bagian yang akan diperoleh petani semakin rendah. Sehingga dengan mongoptimalkan keuntungan petani tambak salah satu yang harus di perhatikan yaitu margin pemasaran, dengan demikian kesejahteraan petani tambak dapat lebih berkembang dengan tujuan melakukan produksi ikan bandeng yang baik lagi.

Farmer's share mempunyai hubungan negatif dengan margin pemasaran dan efisiensi pemasaran, sehingga semakin tinggi margin dan efisiensi pemasarannya maka bagian yang akan diperoleh petani semakin rendah. Hal ini dapat dilihat pada saluran pemasaran I yang memiliki nilai margin pemasaran dan efisiensi pemasaran paling tinggi, sehingga nilai farmer's sharenya lebih rendah dari pada saluran pemasaran II yang memiliki nilai margin pemasaran dan efisiensi pemasaran yang rendah sehingga nilai farmer's sharenya lebih tinggi

\section{KESIMPULAN}

Saluran pemasaran ikan bandeng Di Desa Pitue Kecamatan Ma'rang Kabupaten Pangkajene dan Kepulauan merupakan saluran pemasaran pertama dan saluran pemasaran kedua, dimana saluran pemasaran kedua yang paling efisien karena memiliki sedikit lembaga pemasaran yang terlibat yaitu dari petani tambak, ke pedagang pengecer kemudian ke konsumen, sehingga tingkat biaya pemasaran lebih kecil dan efisien. Sedangkan saluran pemasaran pertama kurang efisien karena memiliki banyak lembaga pemasarannya yaitu dari petani tambak ke pedagang pengumpul, kemudian sebelum sampai ke tangan konsumen mesti melalui pdagang pengecer terdahulu. 
Margin pemasaran pada saluran I lebih besar dibandingkan dengan margin pemasaran saluran II. Pada saluran I margin pemasaran ikan bandeng adalah Rp 6.500/kg. Farmer' share sebesar 72 persen. Sedangkan pada saluran II margin pemasaran ikan bandeng adalah $\mathrm{Rp}$ $5.000 / \mathrm{kg}$. Farmer' share sebesar 79 persen. Hal ini disebabkan karean panjangnya saluran pemasaran dan besarnya biaya pemasaran yang dikeluarkan oleh lembaga pemasaran yang terlibat.

Pemasaran ikan bandeng Di Desa Pitue Kecamatan Ma'rang Kabupaten Pangkajene dan Kepulauan sudah efisien, karena nillai efisiensi pemasaran dari saluran pemasaran I dan II adalah 11,52 persen dan 7,10 persen lebih kecil dari 50 persen. Namun dari kedua saluran pemasaran yang ada, saluran pemasaran II adalah yang paling efisien bagi petani tambak dari pada saluran I. Hal ini disebabkan karena sedikitnya lembaga pemasaran yang terlibat pada saluran pemasaran II sehingga tingkat biaya pemasaran menjadi kecil dan efisien.

\section{DAFTAR PUSTAKA}

BPS. 2013. Kabupaten Pangkep Dalam Angka 2013. BPS Kabupaten Pangkep.

Hanafiah, A. M.dan Saefuddin, A. M. 1986. Tataniaga Hasil Perikanan, UI Press, Jakarta

Kotler, P. 1987. Manajemen Pemasaran : Marketing Management, Analisis, Perencanaan dan Pengendalian. Erlangga. Jakarta.

Kotler, P. 1992. Manajemen Pemasaran : Analisis, Perencanaan, Implementasi dan Pengendalian. Erlangga. Jakarta.

Limbong, S., 1987. Pengantar Tataniaga Pertanian (Bahan Kuliah Jurusan Ilmuilmu Sosial Ekonomi Pertanian). Institut Pertanian Bogor. Bogor.

Mubyargv ggry5333dcto, 1995, Pengantar Ekonomi Pertanian, LP3S, Jakarta.

Rahim dan Hastuti D R D, 2007. Ekonomika Pertanian (Pengantar, Teori dan Kasus). Penebar Swadaya. Jakarta.

Singarimbun, M dan S. Effendi.1995. Metode Penelitian Survey. LP3S. Jakarta.

Soekartawi. 1993. Prinsip Dasar Ekonomi Pertanian (Teori dan Aplikasi).PT Raja Grafindo Persada. Jakarta.
Sudiyono. 2002. Pemasaran Pertanian. UMM Press. Malang.

Soeharjo dan Patong, 1973. Sendi-Sendi Pokok Usaha Tani. Departemen Ilmu Sosial Ekonomi. Fakultas Pertanian, Institut Pertanian Bogor, Bogor.

Swastha, B. 1992.Konsep dan Strategi Analisa Kuantitatif Saluran Pemasaran. BPFE. Yogyakarta. Maret. Surakarta

Swastha, B dan Irawan. 1997 . Manajemen Pemasaran : Analisa Perilaku Konsumen. BPFE. Yogyakarta.

Swastha, B dan Irawan. 2003. Manajemen Pemasaran Modern. Liberty.Yogyakarta. 